\title{
The residual claim of rank and file employees
}

\author{
Bruce A. Rayton \\ University of Bath School of Management, Claverton Down, Bath, BA2 7AY, UK \\ Accepted 22 June 2001
}

\begin{abstract}
This paper estimates the intensity of the value-maximization incentives for average employees generated through the combination of wage, salary, and bonus mechanisms. This is accomplished through estimation of the elasticity of average employee hourly compensation with respect to changes in firm performance. This performance elasticity indicates the degree of alignment between employee and shareholder objectives, and it can also be interpreted as an incomplete residual income claim for employees. The estimated performance elasticity for the full sample of firms is not significantly different from a CEO salary-plus-bonus performance elasticity of 0.1 published in Coughlan and Schmidt [Journal of Accounting and Economics 7 (1985) 43]. Jensen and Murphy [Journal of Political Economy 98 (1990) 225] find that CEOs received approximately US $\$ 3.25$ for each US\$1000 increase in shareholder wealth. This translates to an elasticity of just over 57, but most of these payments come through channels other than salaries and bonuses. Jensen and Murphy report a performance sensitivity of salary and bonus payments for CEOs that is equivalent to analogous elasticities for rank and file workers reported in this paper. While the rewards CEOs receive through salary and bonus channels are larger than those of average employees in absolute terms, these rewards represent comparable fractions of income. This paper also finds differences in the pay-performance link based on firm size. The estimated performance elasticity is 0.197 in small firms and is indistinguishable from zero in large firms. The results indicate that firms use wage, salary and bonus adjustments to direct approximately $5.3 \%$ of firm value increases to employees. Although the precise link between pay and performance is not visible with this data, these results indicate that average employees benefit when the firm performs well.
\end{abstract}

(C) 2001 Elsevier Science B.V. All rights reserved.

Keywords: Residual income claim; Rank and file employee; Shareholder 


\section{Introduction}

The CEO is not the only employee of the firm, and yet much of the literature on incentive compensation focuses exclusively on the pay of CEOs. We can learn valuable lessons from the analysis of CEO compensation, but we must use other approaches if we wish to examine the degree of incentive alignment throughout the firm. Prendergast (1999) supports this view.

[T]he understandable focus of the literature has been on occupations (such as CEOs, mutual fund managers, professional golfers, etc.) for which measures of output are available. However, the majority of workers do not satisfy these criteria. Instead, most workers are evaluated on subjective criteria, where firms choose how to evaluate and how to pay based on those evaluations. Consequently, it seems to me that a critical avenue for future research should be to better understand the evaluation and compensation of those with noncontracted output (p. 11).

The incentives of average employees are an important element in any theory of the firm because incentives determine behavior, and because labor costs represent a large fraction of production costs. Blinder (1990) argues that a given increase in labor productivity can achieve a much greater increase in overall productivity than an analogous increase in the productivity of other inputs, and a complete understanding of average employee incentives is therefore necessary to determine the nature of potential productivity increases.

This paper uses the empirical approach commonly taken in the executive compensation literature and documents the existence of a link between the pay of average employees and the performance of the firm. This result indicates that incentive alignment is an important part of the production process in US manufacturing firms. This link between pay and performance is similar in magnitude and character to the residual income claim of CEOs documented in the executive compensation literature. ${ }^{1}$ It is unclear what mechanisms firms use to tie the pay of average employees to performance, but clearly they do.

This paper furthers our knowledge of incentives by analyzing firm level compensation data. Specifically, this paper analyzes the elasticity of per-employee hourly compensation with respect to changes in firm value. Firms will link the pay of average employees to performance if the consequences of not establishing this link are more costly than the maintenance of incentive contracts. Baker et al. (1988) discuss the merits of different definitions of performance, and the choice of a benchmark will undoubtedly vary across firms, and vary across individuals within the same firm. Regardless of the mechanisms used to measure performance, market value will be positively correlated with employee compensation if firms choose benchmarks that align the objectives of employees with the objectives of shareholders.

\footnotetext{
1 Jensen and Murphy (1990), Coughlan and Schmidt (1985), etc.
} 
Firms have access to many compensatory mechanisms for rewarding good performance. Firms link some forms of compensation directly to performance, but most forms of compensation have only indirect links to performance. Wages, salaries, and bonuses are good examples. These types of pay are unlikely to have any direct link to performance, but firms can indirectly account for past performance when revising wages and salaries, or when granting bonuses. Firms may explicitly tie bonuses to performance, but these awards usually depend on an ex post administrative evaluation. Baker et al. (1988) discuss the problems with subjective evaluations, and Rayton (1995) presents average employee statements documenting the importance of the administrative connection in several firms.

Of course, firms have other incentive alignment tools at their disposal. Firms can use other forms of compensation, promotion incentives, dismissal incentives, monitoring, and other tools to elicit desired behavior from employees, but the use of these tools generates their own costs. For example, Nalbantian and Schotter (1997) use experimental techniques to demonstrate that monitoring is capable of imperfectly maintaining high effort levels, but only if the probability of detection is high. These high detection rates are more costly to maintain than low detection rates, all else equal. Although there are many incentive alignment tools available to firms, $86 \%$ of US employees are paid by the hour or by the month, ${ }^{2}$ so most employees are directly affected by changes in these forms of pay. These employees have a greater incentive to maximize firm value if wage and salary decisions depend on performance, all else equal. This paper focuses on the incentives generated by wages, salaries, and bonuses because these forms of compensation are the most common forms of compensation in the economy, and it seems likely that most firms wishing to provide incentives for their employees to work hard will use these tools to some degree.

\section{Why link pay to performance?}

The average employee of the firm faces decisions on the job: Should I work hard or not work hard? Should I spend the extra time and effort required to use resources efficiently, or should I waste resources (paid for by my employer) to make my work easier? The decisions employees make depend on the relative costs and benefits of available alternatives. Firms can change the structure of the decision problem by rewarding correct behavior with increases in compensation.

The profit-sharing literature finds significant links between the structure of average employee compensation and firm performance. Most of these profit-sharing studies assume that pay causes performance. ${ }^{3}$ The executive compensation literature finds robust empirical indications of a positive link between the pay of CEOs and firm performance. These studies of executives assume that performance causes pay, and they measure CEO claims to changes in firm value. For example, Jensen and Murphy (1990) find a US\$3.25 increase in executive pay for each US\$1000 increase in shareholder wealth, and Coughlan and Schmidt (1985) find that a $1 \%$ increase in firm value leads to a $0.1 \%$ increase in CEO

\footnotetext{
2 Ehrenberg and Smith (1988, p. 408).

3 See Kruse (1993) for an excellent review of the profit-sharing literature.
} 
pay. This paper uses tools from the executive compensation literature to measure the claims of other employees to changes in firm value.

The detection of a significant link between pay and performance for average employees does not imply that the pay of any individual employee is linked directly to stock price, or that the pay of any individual employee should be linked directly to stock price. Linking the pay of average workers directly to stock prices is probably quite inefficient because these employees have very little impact on the overall performance of the firm and these employees are relatively risk averse to firm-specific shocks. However, if employees collectively increase their performance, then we expect firm value to increase as well, and the approach taken in this paper measures the size of the reward employees receive when the firm does well. Although this paper cannot examine the precise nature of the incentive mechanism for any particular employee, this does not preclude the investigation of some interesting hypotheses.

\subsection{Hypotheses}

Several authors examine the incentive structure of compensation contracts at the firm level, but their efforts focus on extremely narrow samples of firms. ${ }^{4}$ Other studies use cross-sectional data that lacks useful firm performance data. ${ }^{5}$ The articles in this body of literature focus on questions that require extremely detailed compensation information, and they must sacrifice on other margins.

This paper extends the literature by applying techniques from the executive compensation literature to the firm-level pay-performance relation. Other authors find significant links between pay and performance for executives, and the existing work on firm-wide incentives focuses on the effects of incentive compensation schemes on profitability. This paper combines these perspectives, and asks:

(i) Does the average employee have a residual claim on firm value?

(ii) Do small firms tie pay more closely to performance than large firms?

The first hypothesis is fundamental. Do firms link the pay of average employees with performance? Empirical models previously used for examination of executive incentives can provide insight into the incentives of other employees. This is an important step toward understanding the role incentives play in compensation contracts.

The second hypothesis, referred to as the size hypothesis, recognizes that firms with higher costs associated with implementation of performance-based pay systems should restrict their use of these systems. Zenger (1994) separates the effects of firm size on optimal contract structure into measurement costs and comparison costs, and I briefly review each of these costs in turn.

Measurement of performance is less costly in small firms. Williamson $(1975,1985)$, Holmstrom (1989), and Rasmusen and Zenger (1990), among others, all argue that small firms have measurement cost advantages that increase the incidence of performance-based

\footnotetext{
4 Medoff and Abraham (1980), Zenger (1994), and Baker et al. (1994a,b) are examples of this literature.

5 Drago and Heywood (1995).
} 
contracts. There are many reasons for this cost advantage of small firms, but one of the primary reasons is the depth of hierarchies. Large firms have multiple layers of managers, and each manager has incentives to manipulate evaluations and rewards to overstate her own performance. Potential manipulation and sheer size make it more difficult for large firms to determine the source of performance changes. Also, such firms have more promotion opportunities available. These relatively high measurement costs discourage the use of performance-based compensation systems.

Comparison costs are another significant cost of incentive contracts. Every employee reevaluates his own compensation relative to the compensation of others whenever one employee receives a pay increase. These comparisons may induce other increases in compensation, or at least cause firms to incur costs of justifying the change. These comparison costs increase with firm size because the set of information about individual performances that is common knowledge shrinks as firm size increases, and the number of individuals to whom the equity of decisions must be justified increases. These effects combine to increase the comparison costs associated with performance-based contracts as firm size increases. Comparison costs may lead firms to raise the compensation of all employees by the same percentage to preserve existing relationships between compensation levels of employees. The minimization of agency costs subject to measurement and comparison costs induces small firms to select higher pay-performance sensitivities than large firms, all other things equal. See Zenger (1994) for a detailed discussion of measurement and comparison costs.

Other explanations for differentials in pay-performance sensitivities by size class include the implicit regulation hypothesis ${ }^{6}$ and heterogeneous supervision costs. ${ }^{7}$ Differentiation between alternative hypotheses is nearly impossible, but these myriad explanations combine to give the size hypothesis a great deal of attention in the incentive compensation literature. Examples include Jensen and Murphy (1990), Garen (1994), and Zenger (1994). Empirical work routinely supports the size hypothesis, but no previous work has used a broad panel of firms to establish the validity of the size hypothesis for average employee compensation.

\section{Empirical model}

This paper examines the link between growth in firm value and growth in pay. Coefficients in this simple model are elasticities, and the sum of the return coefficients $\left(\beta_{0}+\beta_{1}\right)$ is a measure of the alignment of shareholder and employee objectives. The regression equation is

$$
\ln \left(\frac{w_{i, t}}{w_{i, t-1}}\right)=\psi_{\mathrm{SIC}, t} D_{\mathrm{SIC}, t}+\beta_{0} r_{i, t}+\beta_{1} r_{i, t-1}+\omega_{i, t} .
$$

The dependent variable is the growth rate of average hourly pay, $w$, for the $i$ th firm in year $t$. The primary dependent variables are historical growth rates of firm value. These growth

\footnotetext{
6 See Watts and Zimmerman (1986) and Jensen and Murphy (1990).

7 Oi (1990).
} 
rates, $r$, are defined as the rate of return to common stock. Jensen and Murphy (1990) multiply this measure with beginning-of-period firm value to obtain the level change in firm value. This paper uses growth rates because rates of change are preferable to level changes when firms differ in size. ${ }^{8}$ The regression coefficients are directly interpretable as elasticities, and the lag structure allows 2 years for changes in firm value to alter employee pay.

The use of firm-level panel data allows imposition of disaggregated fixed time effects. These fixed effects, imposed at the two-digit industry level, control for industry-specific changes in omitted variables over time. Examples of such changes include cost shocks, industry-specific changes in product demand, and industry-specific changes in market value. Joskow et al. (1993) and Kruse (1993), among others, find significant cross-industry and time series variation in pay-performance sensitivities. The use of disaggregated fixed time effects in this model helps control for these changes because only time-varying shocks entering the model below the two-digit industry level of disaggregation can bias parameter estimates. Regressions using four-digit industry-year fixed effects yield similar results.

\subsection{Effects of output demand shocks}

Output demand shocks can influence wages, and it is important that these effects not drive the results of this paper. Increases in the demand for output generate increases in the derived demand for labor, and this can sometimes lead to increases in wages. Suppose the demand shock in question is a firm-specific increase in output demand. This shock will have no effect on wages if the firm operates in a perfectly competitive labor market. The labor supply curve facing each individual firm is horizontal, and so the firm can alter the number of workers it employs without having any effect on the market wage.

What if the demand shock is not firm-specific, but instead manifests itself at the industry level? In other words, suppose there is a general increase in the demand for the output of a particular industry. Now all firms in the industry experience an increase in the demand for labor, and the net effect of these changes is movement along the existing labor supply curve. The market reaches a new equilibrium at a higher wage level. The industryyear fixed effects in the empirical model control for just this kind of industry-specific wage change.

Lastly, what happens if we move away from a perfectly competitive labor market? Suppose, for example, that there are significant costs of hiring and firing employees. Now firms have an incentive to retain employees in the face of negative demand shocks and to work employees extra hours when faced with positive demand shocks. Employees are routinely paid 1.5 times their normal wage for overtime hours, and increases in hours worked can generate increases in average hourly pay that may be unrelated to incentives. The observed increases in average pay could simply be an optimal response to transaction costs in the labor market. The industry-year fixed effects help alleviate such effects, but only imperfectly. This paper uses industry-level data from the Bureau of Labor Statistics

8 There are greater opportunity costs associated with owning large firms. See Rayton (1995) for further explanation. 
(BLS), detailed in Section 4.1.2, to control for industry-specific fluctuations in hours and overtime. Although the BLS data cannot control for firm-specific changes in hours and overtime, there are good reasons to believe that such fluctuations have strong industryspecific components.

\subsection{Endogeneity of contemporaneous stock returns}

Abowd (1989) documents the endogeneity of current labor costs and current value. He finds a dollar-for-dollar tradeoff between unexpected changes in collectively bargained labor costs and changes in the value of common stock. The salient observations for this paper are that the fiscal-year-end stock market valuation represents firm value after payments to employees, and that rational stockholders will account for the existing contractual structure in the valuation of shares. The market will downwardly adjust firm valuation in response to unexpected performance increases if employment contracts use performance incentives. To illustrate, consider an example of a firm that pays performance-based bonuses to employees that amount to the entire increase in firm performance. This is an example of "giving away the firm" Barzel (1989). The stock market valuation of this firm would remain constant through time if there were no changes in any firm characteristics besides employee performance. Even so, there are significant incentives created by the bonus system. These incentives would be missed because the market valuation of the firm would never reflect the increases in employee performance in any year because these increases would be matched dollar for dollar by increases in current labor costs.

This endogeneity is present in CEO pay regressions, but it can be safely ignored since CEO pay is such a small portion of total costs. The same cannot be said for total labor costs, and so this paper uses a two-stage least-squares model to correct for this endogeneity. The instruments are taken from an empirical model employed in Bhargava (1994). Bhargava uses changes in sales, historical firm performance, and industry-specific fixed time effects as the independent variables in a regression on changes in accounting profit. ${ }^{9}$ This paper uses 3 years of sales growth, two lags of the returns to common stock, and industry-specific fixed time effects to instrument current period common stock returns. Thus, the first stage regression equation is given by

$$
r_{i, t}=\xi_{\mathrm{SIC}, t} D_{\mathrm{SIC}, t}+\alpha_{0} s_{i, t}+\alpha_{1} s_{i, t-1}+\alpha_{2} s_{I, t-2}+\alpha_{3} r_{i, t-1}+\alpha_{4} r_{i, t-2}+\varepsilon_{i, t}
$$

Lagged firm performance is included in Eq. (2) to allow for persistence in firm performance. Mueller (1990) discusses the nature of this persistence at length, but here it is sufficient to recognize that firm performance may exhibit autocorrelation. Sales growth is used as an instrument for common stock returns because it captures the revenue dimension of profitability without serious corruption by labor costs. Models of profitability routinely

\footnotetext{
9 Bhargava (1994) also includes a binary variable indicating the presence or absence of a profit-sharing system. Analogous data is not available at this time for the firms in this sample.
} 
incorporate other variables, such as market share, industry concentration, R\&D expenditure, and advertising intensity. Consistent with the approach of Bhargava, and with certain limitations of the data, these variables are omitted here. To the extent that some of these effects are stable over time, estimation of the model in changes controls for these influences on performance. Furthermore, the industry-specific fixed time effects will control for the influence of any omitted industry-level factors.

Any paper using an instrumental variables technique is vulnerable to criticisms regarding the validity of the instruments selected. This paper is no exception, however, it is hoped that the selection of a vetted model for the first stage regression will blunt any speculation that these instruments have been creatively selected. The two-stage leastsquares estimator has been shown in Monte Carlo studies to have excellent small-sample properties, and the estimates tend to be quite robust to the presence of multicolinearity and specification errors, ${ }^{10}$ and these features make it particularly appropriate for this investigation.

\section{Data}

Data for this paper is drawn from the Standard and Poor's Compustat database and the Bureau of Labor Statistics Current Employment Statistics program. Compustat reports a 20 -year window of annual data for publicly traded firms, and the compilation of three editions of this data provides 22 years of annual data for over 6000 firms. Limitations on data availability within Compustat and the removal of outliers limits the final dataset to 2559 firm-years of data from 255 firms.

\subsection{Construction of dependent variable}

The dependent variable is constructed from the Compustat and BLS data. The construction is governed by

$$
w_{i, t}=\frac{L_{i, t}}{52 N_{i, t}\left(H_{\mathrm{SIC}, t}+\frac{O_{\mathrm{SIC}, t}}{2}\right)}
$$

where $w$, the average hourly labor cost, is based on the labor and related expenses variable, denoted here by $L$. The number of employees is given by $N$, and BLS measurements of average weekly total hours $(H)$ and average weekly overtime hours $(O)$ for production and non-supervisory workers to control compensation data for nonnumeric changes in labor use. Eq. (3) assumes that overtime hours are paid at 1.5 times the base wage. The labor variable and the BLS data on hours and overtime are discussed in some detail below.

\footnotetext{
10 Kennedy (1992, p. 160).
} 


\subsubsection{Compensation data}

I use Compustat's labor and related expenditures variable to measure total compensation. Compustat also reports the number of employees for each firm, and this allows construction of per-employee compensation.

The labor variable represents the costs of employees' compensation and benefits allocated to continuing operations. This variable contains information about the magnitude of annual firm expenditures on wages, salaries, incentive compensation, profit sharing, payroll taxes, pension costs, and some other benefit plans. This variable represents a gross accounting cost of labor. The absence of detailed compensation information precludes the analysis of the incentives generated by different forms of compensation, but the labor variable allows measurement of the overall link between firm performance and average employee pay.

Point estimates based on the labor variable will understate the degree of incentive alignment because firms have many other incentive alignment tools at their discretion, e.g., employee stock options. Most components of the labor variable are usually not tied directly to firm performance, and an insignificant estimate of the relationship between Compustat's narrow definition of compensation and firm performance does not rule out the conclusion that firms tie the pay of average employees to performance. However, any significant relation between Compustat's narrow definition of compensation and firm performance strengthens the argument that compensation contracts throughout the firm reward employees for good performance.

Firms make voluntary reports of the labor variable in their annual reports and corporate 10 -Ks, and only $12 \%$ of Compustat firms choose to report this variable during the sample period. This represents the most severe constraint on the size of the final dataset. ${ }^{11}$ Firms that report the labor variable tend to report it each year, and I have discerned only one obvious criterion differentiating reporting and non-reporting firms. Reporting firms tend to be larger than non-reporting firms. For example, the median value for real total assets in the full Compustat database is approximately US\$46 million. ${ }^{12}$ The median value of total assets among those firms who report the labor variable is US\$1.67 billion. Not only are firms in the Compustat database larger than average firms in the economy, but the firms admitted to the regression data are large in comparison with the average firm in Compustat. Selection bias is a potential problem, but Rayton (1995) finds no evidence of selection biases introduced by the decision to report the labor and related expenses variable. $^{13}$

While these statistical techniques demonstrate that there are no selection biases in the regression coefficients, visual evidence reinforces this point. Table 1 displays the number of firms from each industry that ultimately make it into the regression sample. There are

11 Twenty-nine percent of the observations otherwise eligible for admission to the regression sample do not report the labor and related expenses variable.

12 All dollar values in this paper are reported in constant 1987 dollars.

13 Rayton investigates selection bias using Heckman's two-stage method. This method uses the inverse Mill's ratio (calculated from a probit on the reporting status of the firms) as an explanatory variable in the two-stage least-squares procedure used to generate the baseline results. The inverse Mill's ratio is never found to be significant. This approach is suggested by Hsiao (1986, pp. 198-200) for use with panel data. 
Table 1

Number of firms in each two-digit industry (255 firms)

Firms belonging to industries containing fewer than four firms are subsequently reassigned to SIC 39 to ensure sufficient variation in the regression sample.

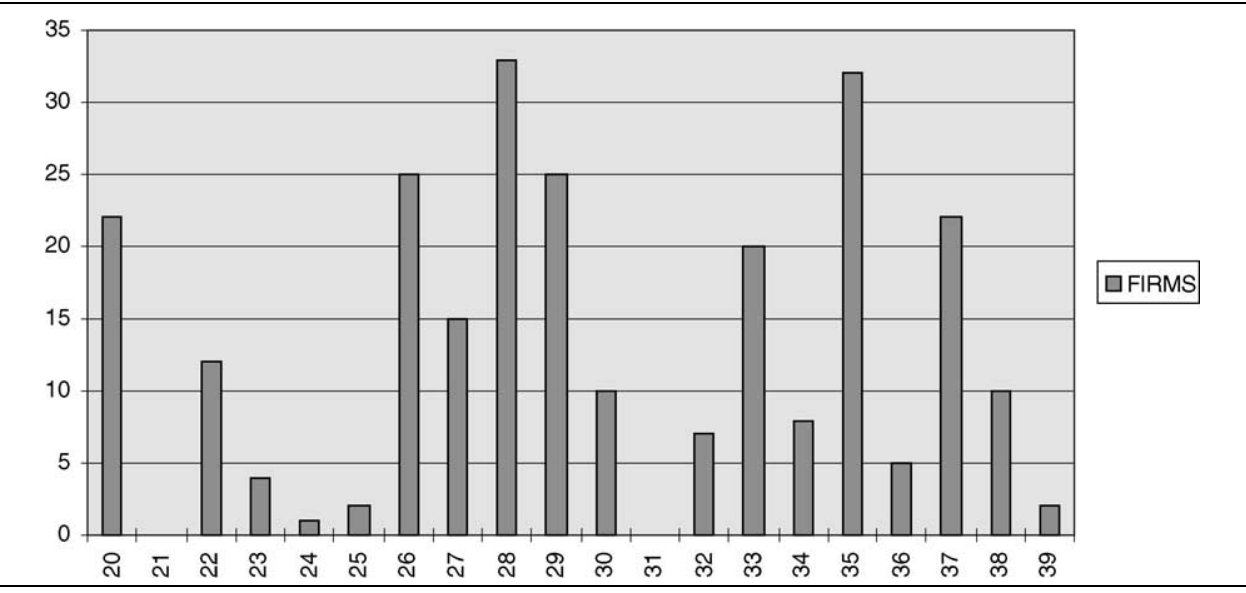

some notable gaps: namely SIC 21 (tobacco products) and SIC 31 (leather and leather products). Industries 24, 25, and 39 (lumber and wood products, furniture and fixtures, and miscellaneous manufacturing, respectively) are combined to ensure sufficient variation in the regression sample.

\subsubsection{Total hours and overtime hours worked}

The Current Employment Statistics Program provides data on employment, hours, and earnings from a broad sample of firms in considerable industrial detail. The Bureau of Labor Statistics (BLS) cooperates with state agencies to collect monthly data from a sample of establishments involved in all non-farm activities. This data is publicly available for most industries at the four-digit level, and is available for all industries at the two-digit level of disaggregation. The data is constructed from a mail survey of approximately 375,000 employer units with over $40 \%$ of total payroll employment. The sample contains about 300,000 employer units for the construction of hours and earnings data for production and non-supervisory workers in private, non-agricultural industries.

I use the measurements of average weekly hours and average weekly overtime hours for production and non-supervisory workers to control compensation data for non-numeric changes in the workforce. It is important to correct for changes in hours because firms change the workload of current employees over the business cycle. Failure to correct for such changes in hours and overtime could induce spurious correlation between compensation expenses and firm value because an expanding economy increases both firm value and the overtime of existing employees. This can raise compensation expenditures for reasons unrelated to incentives. 
I impute BLS industry numbers to all firms in that industry. When four-digit industry data is available I use it, and when it is not available I use the least-aggregated of the available data. The BLS data is available for all industries at the two-digit level, and so all corrections are made at or below this level of aggregation. This approach to controlling for changes in the number of hours worked is obviously imperfect, but the confidentiality of BLS data prohibits more detailed analysis. The BLS data serves as a proxy for firm-level data on annual changes in employee hours, and this proxy will be particularly effective if changes in hours and overtime have industry-specific determinants.

\subsubsection{Unions}

The BLS data cannot control for all changes in workforce composition. These other changes in the composition of the workforce will not bias the parameter estimates as long as the effects can be treated as mean zero measurement error, but there are reasons to think that this may not be the case. For example, when unionized firms lay off workers in recessions they often begin with the least experienced, and thus the lowest paid, employees. This induces a countercyclical component to average hourly pay. Countercyclical average pay introduces a negative bias to the point estimates because increases in average hourly pay accompany recessionary decreases in firm value. The data is insufficient to control for these kinds of non-numeric fluctuations in the labor force, but the use of industry-specific fixed time effects helps to alleviate these data problems. In any event, the biases and inefficiencies introduced by this countercyclical component of average hourly pay only make it harder to accept the hypothesis that pay is linked to performance in these firms.

\subsection{Returns to common stock}

The primary independent variables are growth rates of firm value. I define these growth rates, $r$, as the rate of return to common stock. Common stock returns are calculated as

$$
r_{i, t}=\frac{p_{i, t}+d_{i, t}}{p_{i, t-1}}
$$

where $p_{i, t}$ is the fiscal-year-end price of common stock and $d_{i, t}$ represents dividends per share as reported by Compustat. This represents the change in the value of a share of common stock during year $t$.

I specify the model in growth rates because the influences of time-invariant fixed effects vanish, and because rates of change are preferable to level changes when firms differ in size. ${ }^{14}$ The regression equation includes contemporaneous and lagged values of this growth rate. This lag structure allows current changes in compensation to depend on

\footnotetext{
14 There are greater opportunity costs associated with owning large firms. See Rayton (1995) for further explanation.
} 
past information. Current pay may depend on past performance if there is some delay in the observation of performance, or if there is some structural factor requiring a delay. For example, salary levels set by an annual review mechanism cannot reflect performance changes until the following year. The lag structure used in this paper is consistent with Jensen and Murphy (1990). Unreported regressions using alternate lag structures produce similar results.

The lag structure allows 2 years for returns to alter employee pay. Lagged performance is important because some commonly used forms of pay, e.g., wages and salaries, are not directly linked to performance. These forms of pay can only be adjusted ex post, and annual adjustments of these forms of pay would lead to a link between current pay and lagged performance. The regression coefficients are elasticities, and the sum of the coefficients on firm returns $\left(\beta_{0}+\beta_{1}\right)$ is a measure of the alignment between shareholder and employee objectives.

\subsection{Other data issues}

This paper uses an unbalanced panel because Compustat increased its coverage in the 1980s. Balancing requires either rejecting all firms not covered (or not reporting the relevant variables) in previous years, or restricting the duration of the panel. I admit firms to the dataset that contribute at least five contiguous observations. This allows at least 2 years of data to work completely through the regression equations for each firm. This approach is consistent with Bhargava (1994). I remove the observations from the $1 \%$ tails of each regression variable. This protects against results driven by a few extreme observations. All regressions have been run with outlier cutoffs ranging from $0.5 \%$ to $3.0 \%$. The results are not changed in any significant or systematic manner by these variations in the severity of the outlier removal algorithm. After

Table 2

Full sample: selected firm characteristics, 1974-1992 (255 firms)

This table provides descriptive statistics of key variables for the full sample of firms. The number of employees is the number of company workers as reported to shareholders. Total assets is the value of current assets plus net property, plant and equipment, plus other non-current assets. Annual per-employee compensation is the cost of employee wages and benefits allocated to continuing operations. Hourly compensation is the deconstruction of annual compensation using the number of employees in conjunction with industry-level Bureau of Labor Statistics data on hours and overtime. Firm value and the returns to common stock are constructed from Compustat's data on share prices and shares outstanding. All dollar figures are reported in constant 1987 dollars

\begin{tabular}{lll}
\hline Characteristic & Mean & Median \\
\hline Number of employees & $34,014.87$ & 18,293 \\
Total assets (in millions) & US $\$ 5250.83$ & US $\$ 1850.63$ \\
Annual per-employee compensation & US $\$ 31,599.59$ & US $\$ 31,491.51$ \\
Hourly compensation & US $\$ 14.02$ & US $\$ 13.86$ \\
Change in logarithm of hourly pay & 0.012 & 0.015 \\
Firm value (in millions) & US $\$ 3032.87$ & US $\$ 1107.34$ \\
Returns to common stock $(\%)$ & 4.41 & 2.48 \\
\hline
\end{tabular}


Table 3

Small firms: selected firm characteristics, 1974-1992 (131 firms)

Dollar figures reported in constant 1987 dollars.

\begin{tabular}{lll}
\hline Characteristic & Mean & Median \\
\hline Number of employees & $12,557.82$ & 6700 \\
Total assets (in millions) & US\$1589.26 & US\$538.91 \\
Annual per-employee compensation & US\$30,133.93 $\$$ US $\$ 29,594.83$ \\
Hourly compensation & US\$13.35 & US\$13.20 \\
Change in logarithm of hourly pay & 0.011 & 0.013 \\
Firm value (in millions) & US\$877.89 & US\$362.30 \\
Returns to common stock $(\%)$ & 5.4 & 2.48 \\
\hline
\end{tabular}

creation of lags and removal of outliers there are 255 surviving firms contributing over 2500 firm-years from 1974-1992.

\section{Descriptive statistics}

Tables 2-4 present the means and medians of relevant variables. These tables demonstrate several features of the data. The Compustat database tends to over-sample large firms. Voluntary reporting of the labor variable exacerbates this bias. As a result, I am not surprised that the median firm in the regression sample employs 18,293 employees and has total assets valued at over US $\$ 1.8$ billion. Such measures of size demonstrate the skewness of the sample. The mean market value is just over US\$3 billion while the value of the median firm is US\$1.1 billion.

For consistency with Jensen and Murphy (1990), I base the separation of large and small firms on market value. The separation criterion classifies firms larger than the median size of other firms in the same industry as large firms. This avoids separation of the sample based exclusively on industry-specific characteristics. There are technological reasons to expect differences in the market values of firms in different industries. The subsamples in this paper contain roughly equal numbers of firms from each industry, and this means industry-specific factors cannot explain differences in coefficient magnitudes. This also mitigates rent-sharing explanations for average employee performance elasticities because these effects are equal across the size classes if the extent of rent-sharing is

Table 4

Large firms: selected firm characteristics, 1974-1992 (124 firms)

Dollar figures reported in constant 1987 dollars.

\begin{tabular}{lll}
\hline Characteristic & Mean & Median \\
\hline Number of employees & $51,687.68$ & $35,139.50$ \\
Total assets (in millions) & US $\$ 8136.63$ & US\$3275.53 \\
Annual per-employee compensation & US $\$ 32,638.53$ & US $\$ 32,841.68$ \\
Hourly compensation & US\$14.51 & US $\$ 14.42$ \\
Change in logarithm of hourly pay & 0.013 & 0.016 \\
Firm value (in millions) & US $\$ 4758.01$ & US\$2178.31 \\
Returns to common stock $(\%)$ & 3.64 & 2.51 \\
\hline
\end{tabular}


industry-specific. The size hypothesis should be harder to verify if rent-sharing behavior is an increasing function of union density because employees in large firms are more likely to be unionized than employees in small firms. ${ }^{15}$

Median hourly compensation is US\$13.86, and median total compensation is US $\$ 31,491$. These compensation figures reflect the sample's bias toward large firms. ${ }^{16}$ Not only is the average level of compensation high in the entire sample, but median hourly compensation in large firms is about $9.2 \%$ higher than median hourly compensation in small firms.

\section{Empirical results}

This section presents the empirical results summarized in Table 5. The results indicate a significant positive relationship between the growth rate of firm value and the growth rate of hourly compensation to average employees. The results are not significantly different from those reported for CEO salary-plus-bonus in Coughlan and Schmidt (1985) and Jensen and Murphy (1990). Also, small firms tie pay more closely to performance than large firms. These results are surprisingly large, and they demonstrate that firms use wages, salaries, and bonuses to create incentives for average employees to maximize firm value.

\subsection{Average employee results}

Point estimates from a two-stage least-squares regression over the full sample of data indicates that firms link the pay of the average employee to firm performance. The individual coefficients for the impact of contemporaneous and lagged firm growth on wage growth are significant at the $1 \%$ and $5 \%$ levels, respectively. The overall link between pay and performance, measured by the sum of the individual coefficients, is significant at the $1 \%$ level. These results indicate that the average employee of an average firm has a performance elasticity of compensation equal to 0.150 . This means that a doubling of firm value eventually results in a $15 \%$ increase in pay.

This estimated pay-performance elasticity for average employees is small, but the estimate is not significantly different from the elasticities reported for CEOs. Coughlan and Schmidt (1985) use a specification similar to the one used in this paper, and they report an elasticity of CEO salary-plus-bonus of 0.1. Jensen and Murphy (1990) compare their results with those of Coughlan and Schmidt by multiplying the elasticity estimate by the median pay to value ratio from their sample $(0.057 \%) .{ }^{17}$ Reversal of this process facilitates the comparisons here. Jensen and Murphy's estimated performance sensitivity of CEO salary-plus-bonus of 1.35 cents per US\$1000 change in shareholder wealth converts

\footnotetext{
15 Rayton (1997) examines the link between rent-sharing and incentive explanations for the link between pay and performance in more detail.

16 See Oi (1990) for several explanations of the size-wage premium.

17 Jensen and Murphy (1990, p. 5).
} 
Table 5

Estimates of performance elasticity of per-employee hourly compensation

This table presents two-stage least-squares regression estimates for the full sample, and for the small firm and large firm sub-samples. The dependent variable in all three regressions is the change in the natural logarithm of average employee hourly compensation. All three regressions suppress the coefficients for the fixed time effects. These fixed effects enter the regression model at the two-digit SIC level of disaggregation. For computational ease the traditional intercept terms in these regressions have been omitted rather than one of the fixed effects. $T$ statistics are in parentheses.

\begin{tabular}{llll}
\hline Independent variable & All firms & Small firms & Large firms \\
\hline Number of firms & 255 & 131 & 124 \\
Sample size & 2559 & 1183 & 1348 \\
$R^{2}$ & 0.1796 & 0.2298 & 0.2967 \\
Return to common stock $(t)$ & $0.134155(3.784)$ & $0.167601(3.110)$ & $0.069251(1.679)$ \\
Return to common stock $(t-1)$ & $0.016224(2.195)$ & $0.029591(2.365)$ & $0.005492(0.592)$ \\
Estimated performance elasticity & $0.150379(3.809)$ & $0.197192(3.248)$ & $0.074743(1.647)$ \\
\hline
\end{tabular}

to a performance elasticity of approximately 0.02 . The better known result from Jensen and Murphy (1990) is that CEOs receive US\$3.25 per US\$1000 change in shareholder wealth. This converts to a performance elasticity of just in excess of 57 , but this result is based on a much broader definition of compensation which includes stock options and fluctuations in the value of stock holdings. While CEO pay is more closely linked to firm performance overall, the performance sensitivity of CEO salary-plus-bonus is not significantly different from that of rank and file employees.

The relative magnitudes of CEO and average employee performance elasticities is somewhat surprising. It seems reasonable that the pay of CEOs should be more sensitive to performance than the pay of other employees because CEOs have more control over firm value. This intuition is consistent with the evidence at hand. Differential use of other incentive mechanisms can explain the relative magnitudes of these coefficients. Firms appear to use tools not contained in the Compustat data (such as stock options) to compensate CEOs, while these tools are not used (or are used less) to compensate average employees. The influence of these unobserved tools will not contribute to point estimates based on the Compustat data.

This interpretation of the results is further supported by the findings of DeAngelo and DeAngelo (1992). They find, "pervasive evidence that sample firms' requests for union concessions are accompanied by sacrifices by top management and white-collar workers." 18 DeAngelo and DeAngelo report several pieces of anecdotal evidence, as well as regressions of changes in CEO pay (annual salary plus bonus) on changes in annual operating cash flows and a dummy variable that equaled one in union negotiation years. They found that executive pay increased with cash flow and was inversely related to this dummy variable. This is more evidence of a link between the pay of executives and the rank and file.

While not significantly different, the point estimates reported in this paper are larger than comparable estimates for CEOs. This is consistent with the idea that explicit links between pay and performance make less sense for ordinary workers. Firms may choose to

\footnotetext{
18 p. 21.
} 
avoid high power incentive pay mechanisms, and instead use more subjective mechanisms such as bonuses, wage adjustments, and salary adjustments.

Although this paper has no information on other forms of incentive alignment tools, the reported coefficients represent a significant amount of compensation that firms devote to aligning employee and shareholder incentives. Application of these point estimates to the average firm in the sample indicates that a 1\% increase in value results in US\$1.62 million in performance-based changes in pay. These pay changes translate to over US\$7 million in the average year, and this is substantially more than can be accounted for by changes in CEO compensation. ${ }^{19}$

Positive pay-performance relationships imply ownership. CEOs have a well-documented residual claim on the firm. This paper demonstrates that CEOs are not the only employees with a stake in firm performance. Firms direct approximately $5.3 \%$ of firm value changes to employees through salary, wage, and bonus adjustments. ${ }^{20}$ The gains of winning firms accrue not only to shareholders and CEOs, but also to average employees.

\subsection{Results by size class}

Small firms have cost advantages in implementation and maintenance of incentive contracts, and the executive compensation literature finds that performance-based pay is less common for CEOs of large firms than for CEOs of small firms. These same cost advantages enjoyed by small firms are also evident in the compensation of average employees: the pay of average employees of large firms is less sensitive to performance than the pay of average employees of small firms.

I define large firms as companies with market values exceeding the value of the median firm. ${ }^{21}$ I use industry-specific medians as benchmarks so each category will contain firms from each industry. This avoids the separation of firms based on technological factors, and this also means that industry-specific factors cannot account for observed differences in point estimates across the resulting sub-samples.

The regression over the large firms yields positive point estimates, but these estimates are not significantly different from zero. The sum of the coefficients is 0.074743 , and this sum is also insignificant. It appears that large firms do not tie the compensation of the average employee to firm performance. If they do tie pay to performance, then it seems to occur with substantial delay or with forms of compensation excluded from the Compustat data. $^{22}$

These results may indicate that the costs of linking pay and performance are simply too high for large firms. They may also point to the relative price of compensatory and non-

\footnotetext{
19 Coughlan and Schmidt (1985) report that CEOs receive on average US\$825,000 per year in salary plus bonus. Applying their elasticity estimate of 0.1 , there would have to be over 1900 employees paid in exactly the same fashion as the CEO to account for the observed level of incentive pay. The application of more realistic assumptions governing the decline in salary as we move down the corporate hierarchy will further increase this number.

20 US\$1.62 million divided by one \% of market value from Table 2 yields $5.3 \%$

21 Jensen and Murphy (1990) use market value to measure firm size.

22 Changes in the lag structure have little effect on the results. Addition of a second lag yields insignificant point estimates.
} 
compensatory incentive alignment techniques. The tournament literature predicts that large firms have a greater ability to exploit promotion ladders as incentive alignment mechanisms. A firm characterized by a stable "up or out" tournament structure could exhibit a zero pay-performance relationship in this data, but it may have substantial incentives associated with the promotion potential for each employee. An example will clarify this point.

Assume the firm hired a new "class" of players into the bottom of the hierarchy each year, retired the employee at the top of the hierarchy each year, and either promoted or dismissed all other employees. Further assume that the real compensation for an employee at a given level of the firm hierarchy is constant over time. Each year the firm would pay exactly the same amount in compensation. The estimated payperformance sensitivity would be zero, but there are incentives for employees to work hard if they can enhance their probability of advancing to the next level of the firm hierarchy.

This regression model cannot capture these kinds of incentives. ${ }^{23}$ The results indicate that large firms do not use Compustat measures of compensation to link employee and shareholder objectives. It is possible that large firms are substituting other incentive mechanisms, such as promotion incentives, for compensatory arrangements, but empirical verification of this hypothesis is beyond the scope of this paper.

Small firms appear to tie the pay of average employees to the performance of the firm. The coefficient for the impact of contemporaneous firm growth on changes in compensation is 0.167601 , and this coefficient is significant at the $1 \%$ level. The coefficient for the impact of the first lag of firm growth is 0.029591 , and this coefficient is significant at the $5 \%$ level. The sum of the value coefficients equals 0.197192 , and the null hypothesis that the sum of the value coefficients equals zero is rejected at the $1 \%$ level. These results indicate that small firms link the pay of the average employee to firm performance, and that over $5.3 \%$ of any change in firm value is directed to employees through wage, salary, and bonus adjustments. The coefficient sum for the small firm regression is significantly different from the coefficient sum for the large firm regression, and this difference is the strongest indication of the difference between the compensation practices of large and small firms.

\section{Conclusion}

The CEO is not the only employee with a residual claim. Average employees also have a stake in firm performance. The precise mechanisms used to establish this link undoubtedly vary from firm to firm, but the result is clear: firms link the pay of average employees to firm performance.

This paper employs tools from the executive compensation literature to analyze a new and interesting aspect of the use of firm-wide incentive contracts. The average employee

\footnotetext{
23 Tournament structures can influence the estimates if there are errors in the measuring and rewarding of employee performance, and if these errors are correlated with firm performance. Although the data is biased against finding a relationship between pay and performance, the bias may not be as large as expected.
} 
receives a $0.15 \%$ increase in compensation when the firm increases in value by $1 \%$. This represents over US\$7 million in performance-based changes in pay for the average firm in the average year. The magnitude of the performance-elasticity of average employee hourly compensation also varies with the predictions of agency theory. Small firms tie the pay of employees more closely to performance than large firms. These results do not imply that the pay of any individual employee is directly linked or should be directly linked to market performance, but these findings do indicate the existence of some form of incentive arrangement. These results are consistent with the findings of the executive compensation literature, and they document the importance of incentive alignment on a firm-wide basis. Incentive contracting is not something exclusively for CEOs. Average employees benefit when the firm does well, and these benefits provide incentives to increase firm value.

\section{Acknowledgements}

I thank Bob Parks, Lee Benham, and Fred Raines for their advice and suggestions. I also thank Don Cox, Bob Carpenter, Keith Crocker, Bob Drago, Tim Dunne, Gerry Garvey, Jeanine Balbach, Ken Lehn, Andy Meyer, Mark Schnitzler, Darrell Williams, and Todd Zenger. The paper has also benefited from the comments of three anonymous referees. Remaining errors are my responsibility.

\section{References}

Abowd, J.M., 1989. The effect of wage bargains on the stock market value of the firm. American Economic Review 79, 774-800.

Baker, G.P., Jensen, M.C., Murphy, K.J., 1988. Compensation and incentives: practice vs. theory. Journal of Finance 43, 593-616.

Baker, G.P., Gibbs, M., Holmstrom, B., 1994a. The internal economics of the firm: evidence from personnel data. Quarterly Journal of Economics 109, 881-919.

Baker, G.P., Gibbs, M., Holmstrom, B., 1994b. The wage policy of a firm. Quarterly Journal of Economics 109, 921-955.

Barzel, Y., 1989. Economic Analysis of Property Rights. Cambridge University Press, Cambridge.

Bhargava, S., 1994. Profit sharing and the financial performance of companies: evidence from UK panel data. The Economic Journal 104, 1044-1056.

Blinder, A.S., 1990. Paying for Productivity: A Look at the Evidence. The Brookings Institution.

Coughlan, A.T., Schmidt, R.M., 1985. Executive compensation, management turnover, and firm performance. Journal of Accounting and Economics 7, 43-66.

DeAngelo, H., DeAngelo, L., 1992. Union negotiations and corporate policy: a study of labor concessions in the domestic steel industry during the 1980s. Journal of Financial Economics 30, 3-43.

Drago, R., Heywood, J.S., 1995. The choice of payment schemes: Australian establishment data. Industrial Relations 34, 507-531.

Ehrenberg, R.G., Smith, R.S., 1988. Modern Labor Economics, 3rd edn. Scott Foresman and Company, Glenview.

Garen, J.E., 1994. Executive compensation and principal-agent theory. Journal of Political Economy 102, $1175-1199$.

Holmstrom, B., 1989. Agency costs and innovation. Journal of Economic Behavior and Organization 12, $305-327$ 
Hsiao, C., 1986. Analysis of Panel Data. Cambridge Univ. Press, Cambridge.

Jensen, M.C., Murphy, K.J., 1990. Performance pay and top management incentives. Journal of Political Economy $98,225-264$.

Joskow, P.L., Rose, N.L., Shepard, A., 1993. Regulatory constraints on CEO compensation. Brookings Papers on Economic Activity 1, 1-58.

Kennedy, P., 1992. A Guide to Econometrics, 3rd edn. MIT Press, Cambridge.

Kruse, D.L., 1993. Profit Sharing: Does it Make a Difference. W.E. Upjohn Institute for Employment Research, Kalamazoo.

Medoff, J.L., Abraham, K.G., 1980. Experience, performance, and earnings. Quarterly Journal of Economics 95, 703-736.

Mueller, D., 1990. The Dynamics of Company Profits: An International Comparison. Cambridge Univ. Press, Cambridge.

Nalbantian, H.R., Schotter, A., 1997. Productivity under group incentives: an experimental study. American Economic Review 87, 314-341.

Oi, W.Y., 1990. Employment relations in dual labor markets ('It's Nice Work If You Can Get It'). Journal of Labor Economics 8, 124-149.

Prendergast, C., 1999. The provision of incentives in firms. Journal of Economic Literature 38, 7-63.

Rasmusen, E., Zenger, T., 1990. Diseconomies of scale in employment contracts. Journal of Law, Economics, and Organization 6, 65-92.

Rayton, B.A., 1995. The CEO is Not the Only Employee of the Firm: An Empirical Investigation of Firm-Level Pay-Performance Relationships. PhD dissertation, Washington University-St. Louis.

Rayton, B.A., 1997. Rent-sharing or incentives? Estimating the residual claim of average employees. Applied Economics Letters 4, 725-728.

Watts, R.L., Zimmerman, J.L., 1986. Positive Accounting Theory. Prentice-Hall, New York.

Williamson, O.E., 1975. Markets and Hierarchies: Analysis and Antitrust Implications. The Free Press, New York.

Williamson, O.E., 1985. The Economic Institutions of Capitalism The Free Press, New York.

Zenger, T.R., 1994. Explaining organizational diseconomies of scale in R\&D: agency problems and the allocation of engineering talent, ideas, and effort by firm size. Management Science 40, 708-729.

\section{Further reading}

Alchian, A.A., Demsetz, H., 1972. Production, information costs, and economic organization. American Economic Review 62, 777-795.

Ang, J.S., Fatemi, A., 1995. The alignment of management and employee compensations: the case of UK firms. Journal of Multinational Financial Management 5, 73-85.

Cable, J.R., Wilson, N., 1989. Profit sharing and productivity: an analysis of UK engineering firms. Economic Journal 99, 366-375.

Carpenter, R.E., Fazzari, S.M., Petersen, B.C., 1994. Inventory investment, internal finance fluctuations, and the business cycle. Brookings Papers on Economic Activity 2, 75-138.

Christofides, L., Oswald, A.J., 1992. Real wage determination and rent-sharing in collective bargaining agreements. Quarterly Journal of Economics 108, 985-1002.

Coase, R.H., 1960. The problem of social cost. Journal of Law and Economics 3, 1-44.

DeGroot, M.H., 1986. Probability and Statistics, 2nd edn. Addison-Wesley Publishing, Reading.

Greene, W.H., 1993. Econometric Analysis, 2nd edn. MacMillan, New York.

Hausman, J.A., 1983. Simultaneous equation models. In: Griliches, Z., Intriligator, M.D. (Eds.), Handbook of Econometrics, vol. 1. North-Holland, Amsterdam, pp. 430-436.

Holmstrom, B., 1982. Moral hazard in teams. Bell Journal of Economics 13, 324-340.

Jensen, M.C., Meckling, W.H., 1976. Theory of the firm: managerial behavior, agency costs, and ownership structure. Journal of Financial Economics 3, 305-360.

Lazear, E.P., Rosen, S., 1981. Rank-order tournaments as optimum labor contracts. Journal of Political Economy 89, 841-864. 
Masson, R.T., 1971. Executive motivations, earnings, and consequent equity performance. Journal of Political Economy 79, 1278-1292.

Rosen, S., 1991. Transactions costs and internal labor markets. In: Williamson, O., Winter, S.G. (Eds.), The Nature of the Firm. Oxford Univ. Press, New York, pp. 75-89.

Spear, S., Srivastava, S., 1987. On repeated moral hazard with discounting. Review of Economic Studies 54, 599-617. 